\title{
Vertical stratigraphic variations and sedimentation model of the Lower Siwalik sequence in Kumaun Himalaya, India
}

\author{
UK Shukla ${ }^{1 *}$ and DS Bora ${ }^{2}$ \\ 1 Department of Geology, Banaras Hindu University, Varanasi-221005, INDIA \\ 2 Schlumberger Asia Services Limited, DCS, Mumbai, INDIA \\ * For correspondence, email: shukla_umakant@yahoo.com
}

Lower Siwalik sequence of Kumaun Himalaya is about 300$900 \mathrm{~m}$ thick and shows characteristic stratigraphic changes in sedimentation pattern. Available magnetostratigraphic dates indicate Late Miocene age. Based on detailed facies analysis four depositional settings are identified namely Sandstone Succession (Channel deposits), Mudstone Succession (Floodplain deposits), Mottled Mudstone Succession (Palaeosols), and Mottled Siltstone Succession (Interfluve deposits). Stratigraphic succession shows systematic changes of facies association, palaeocurrent and petrography and palaeochannel patterns. Starting from base, about $500 \mathrm{~m}$ thick, coarsening upward Megacycle $\mathrm{A}$ is internally made up of two Mesocycles I and II. The sequence is made up of meandering and anastomosing rivers towards the base (Mesocycle I) that gradually evolve into braided towards top (Mesocycle II). This megacycle indicates sedimentation in a narrow subsiding basin by prograding mega fans. The Megacycle evolved under initially more pronounced tectonic activation in the source terrain (hinterland tectonism) and sub humid climatic conditions, gradually followed by episodic tectonics and more humid climate towards the later phases of sedimentation.

In contrast, following about $400 \mathrm{~m}$ thick Megacycle B, made up of two Mesocycles III and IV, is fining upward. This sequence is made up of thickly developed meandering - braided river systems at the base interbedded with thick interfluve and distal flood plain deposits (Mesocycle III) that gradually becomes thinner towards top, and river system changes to predominantly meandering type (Mesocycle IV). Megacycle B seems to represent sedimentation in a rather wide and tectonically active basin, characterized by incision of rivers. The Megacycle evolved under intense intrabasinal tectonism, and humid climatic conditions in the beginning that gradually changed to rather drier phases. The eustatic changes of more than $140 \mathrm{~m}$ during the Lower Siwalik times may have also contributed to base-level changes leading to incision of rivers particularly away from the orogen in the distal alluvial plain settings. 